\title{
R\&D FUNDING POLICY AND UNIVERSITY-INDUSTRY RESEARCH COLLABORATION IN BRAZIL: THE CASE OF PETROBRAS
}

\author{
Giovanna G. Gielfi ${ }^{1 *}$, André Furtado ${ }^{1,}$ Robert J. W. Tijssen² \\ ${ }^{1}$ University of Campinas, Institute of Geosciences, Department of Science and Technology \\ Policy, Campinas, Brazil \\ ${ }^{2}$ Leiden University, Centre for Science and Technology Studies (CWTS), PO Box 905, 2300 \\ AX Leiden, The Netherlands \\ *Corresponding author: giovannagielfi@ige.unicamp.br / giovannaggielfi@gmail.com
}

Resumo: Este artigo busca analisar a colaboração universidade-empresa no desenvolvimento tecnológico da Petrobras, a empresa petrolífera estatal brasileira. Através das informações das patentes depositadas pela Petrobras, extraídas da base de dados PatStat, buscou-se identificar dentre as patentes da estatal aquelas que possuem colaboração com as universidades. Para tanto, foram listados todos os inventores e seus nomes buscados na Plataforma Lattes de forma a identificar os inventores acadêmicos e, consequentemente, as patentes co-inventadas com universidades. Com base nesses dados, foram analisadas a contribuição da colaboração com universidades para o desenvolvimento tecnológico da Petrobras e as principais áreas tecnológicas em que ocorre a colaboração. Além disso, foi investigado o efeito da recente política de financiamento à $P \& D$ na colaboração Petrobras-universidades. Os principais resultados obtidos revelam uma tendência crescente na colaboração Petrobras-universidades no desenvolvimento de patentes, fomentada pela política de financiamento à $\mathrm{P} \& \mathrm{D}$, e que propiciou a expansão na rede de colaborações da estatal. Contudo, os resultados levantam dúvidas quanto a efetiva contribuição das universidades para o fortalecimento das capacitações tecnológicas da Petrobras, uma vez que a colaborações está concentrada em áreas de nicho e backgroung. Por fim, a partir dos resultados obtidos, são discutidas as implicações de políticas para o fortalecimento das capacidades tecnológicas da Petrobras, bem como do sistema de inovações brasileiro de petróleo e gás natural.

\begin{abstract}
This paper aims to analyze the university-industry collaboration on the technological development of Petrobras, the Brazilian state-controlled oil company. Based on inventors' names, extracted of patent applications by Petrobras gathered from the PatStat database, and ancillary information from Lattes Platform, we identify the academic jointpatents within Petrobras' patent portfolio. Then we analyze the contribution of university collaboration to support the firm's technological development and its main technical areas. Furthermore, we examine changes in collaboration overtime to explore if the recent R\&D funding policy has affected the Petrobras-university interactions. The main findings of this study reveal an upward trend in Petrobras-university inventive collaboration, which is fostered by the R\&D funding policy, resulting in an enlargement of the Petrobras' collaborative network. We have also found that universities make background and niche contributions to Petrobras' patenting activities, raising questions about whether collaboration has effectively contributed to strengthen the technological capabilities of the company. The implications of these results to enhance the $\mathrm{R} \& \mathrm{D}$ resources and capabilities of Petrobras, as
\end{abstract}


well as to strengthen the Brazilian system of innovation related to oil and gas activities, are also discussed.

Keywords: university-industry collaboration; R\&D funding; academic patents; patent analysis; Brazil; oil industry

Palavras-chave: colaboração universidade-empresa; financiamento à P\&D; patentes acadêmicas; análise de patentes; Brasil; indústria petrolífera

JEL classification: I23, O32

Área ABEIN: 6-Redes de inovação - alianças de P\&D, interações universidade-empresa, cadeias

Acknowledgments: This work was supported by CAPES Foundation [BEX 10715/14-2]. The first author also would like to thank the National Council for Scientific and Technological Development (CNPq) for the regular PhD scholarship in Brazil. We would like to thank our CWTS colleague, Jos Winnink, for his assistance and technical support to the data analysis. 


\section{Introduction}

Several empirical studies have shown the contribution of universities to industrial innovation (Cohen et al., 2002; Mansfield, 1995; Narin et al., 1997), as well as the role played by them in national innovation systems (Mazzoleni, 2008; Mowery and Sampat, 2005). However, empirical knowledge regarding university-industry research collaboration impacts on the technological development of firms remains limited. This paper helps to fill this gap by analyzing university-industry collaboration in Brazilian oil industry over the last 30 years using patent data. The work is framed in the systems of innovation concept and its methodological approach introduces - to the best of our knowledge - a novelty to studies on university-industry collaboration in Brazil, since it builds upon the company's patent portfolio data to track academic inventors collaborating with the company in patenting. Thus, uncovering the contributions of universities to the technological development of the firm.

The paper investigates the case of a Brazilian national champion firm, Petrobras, which plays a leading role in the evolution of the national system of innovation in Brazil. The choice of Petrobras was based on a theoretical sampling strategy (Eisenhardt, 1989) in which the case was selected by providing a polar example of well-established collaboration between a firm and universities. Beyond that, the choice is justified by the role that Petrobras has been playing in advancing and strengthening scientific and technological capabilities in Brazil, as well as its importance to the country's economy.

We question whether collaboration with universities has supported Petrobras' technological development within patents, and, if so, to what extent universities are bringing new technical expertise or reinforcing the technological core of Petrobras. We also want to explore the effects of the R\&D funding policy on Petrobras-universities collaboration. To do so, we analyze whether the intensity of collaboration has substantially changed after the establishment of R\&D funding instruments.

To address these research questions, the approach taken in this paper focuses on the Petrobras-universities inventive collaboration. We use patent data of Petrobras to identify joint-academic patents within the patent portfolio of the company. In doing so, we use Petrobras academic joint-patents to measure the intensity of collaboration and its trends overtime. We also use patent information to capture the extent to which universities contribute to Petrobras' technological development in different technical areas. The remainder of the paper is organized as follows: section 2 introduces the analytical framework that guided our analysis, section 3 explains the methodological procedures adopted, and section 4 presents the results. Section 5 concludes the paper discussing research and policy implications.

\section{Analytical framework}

\subsection{University-industry interactions and technical change}

The concept of National Systems of Innovation appeared in the late 1980s (Freeman, 1987; Lundvall, 1992; Nelson, 1993) and has been developed and widely adopted in academic and policy circles. A system of innovation comprises organizations and institutions, and the interactions between them. Organizations are the actors such as the firms, universities, other public research organizations, policy or regulatory agencies. Among those, firms are considered a key actor, occupying a central position in the system of innovation. Institutions 
are the "rules of the game", i.e., the rules and norms influencing the relations between the actors, for example, the intellectual propriety rights laws, and norms influencing universityindustry relationships. The approach stresses the importance of the interactions between the actors on innovation process, in which the dynamic of interactions (the intensity and strength of the links) shapes economic development.

The relations between firms and universities are considered one of the core aspects of a system of innovation. Universities are recognized as an important source of knowledge and skills for industry (Klevorick et al., 1995), besides their generic contributions to economy (Pavitt, 1991; Salter and Martin, 2001). University-industry relationships have a varied nature of links, like research partnerships, research services, informal contacts and networks, human resources, patents and publications (Perkmann and Walsh, 2007). These links are often used simultaneously and in succession (Cohen et al., 2002; Meyer-Krahmer and Schmoch, 1998). Furthermore, empirical evidence shows that these links and their intensity differ across countries (Campos, 2010; Dutrénit and Arza, 2010) and they are often sector- and/or technology- specific (Bekkers and Bodas Freitas, 2008; Laursen and Salter, 2004).

Despite the vast theoretical and empirical literature about university-industry collaboration, the impact of academic research on innovation/technological development are still subject of research and scholarly debate (Tijssen, 2005). The main methodological challenges in measuring and assessing this are related to data availability and measurability. For this reason, to focus on the contribution of university-industry collaboration on technological development we adopt joint-invented patents as a measure of the intensity of Petrobrasuniversities collaboration.

Patents are frequently adopted as a proxy of technological production, and its usage has been extensively debated in the literature (Griliches, 1990; Narin et al., 1987; Pavitt, 1988; Trajtenberg, 1990). Moreover, patents applications are recognized as a very good proxy of firms' technological competencies (Breschi et al., 2003). Patent data have advantages and drawbacks in reflecting inventive activities. The main advantages are: data are readily available and easily accessible from patent offices; data has a unique spatial and temporal coverage; it enables standardized quantitative information and detailed information on the invention process. However, patent data have some noteworthy drawbacks: not all inventions are patented; there significant differences in patenting propensity amongst sectors; the value distribution of patents is highly skewed (many patents have no industrial application); differences in patents laws around the world and their changes over time require caution in benchmarking and trend analysis (OECD, 2009).

The use of patent data to measure the contribution of universities to technological advance and innovation has been growing adopted, but it remains a subject of debate. Pavitt (1998) was one of the first scholars to question whether "patents reflect the useful research output of universities" and concludes that patents granted to universities provide a very partial and distorted indicator of the contribution of universities to technical change. This question was remade by Meyer (2003) using a different approach tracking patents related to universities by the inventors rather than university ownership. The key idea is that there are two different types of university patents: the ones that are owned by the university (i.e. it has the university as the applicant), and those that are not owned by the universities but were invented by researchers who are employed by the universities - the so called academic patents. The analysis confirms Pavitt's affirmation that patents granted to universities are not a robust 
indicator of the contribution of academic research to technological advance. However, it shows that academic patents are a reasonable indicator of the inventive output of universities.

Further empirical evidence has shown that the number of university patents is substantially underestimated when only patents with universities as applicants are take into account (Geuna and Nesta, 2006; Silva et al., 2014) and reaffirmed the use of a academic patent data as a reasonable proxy of the contributions of universities to technical advance (Lissoni, 2012; Thursby et al., 2009) and economic activity (van Dongen et al., 2014).

\subsection{University-industry collaboration in Brazil}

Empirical evidence have shown the considerable contribution of university research to industrial innovation (Cohen et al., 2002; Narin et al., 1997), as well as their role supporting economic catching-up process (Mazzoleni and Nelson, 2007), in both developed (Mowery and Sampat, 2005) and developing economies (Albuquerque et al., 2015). Furthermore, the fact that universities are the main public organizations performing R\&D in most countries innovation systems put them in a prominent position. Awareness of the potential benefits of university-industry collaboration to innovation process have prompted many governments to adopt policies fostering this relationships (Currie, 2011; OECD, 2013; Velho et al., 1998).

Following these trends, since 1970's the Brazilian government has stimulated universityindustry collaboration, directly or indirectly, via polices or governmental plans (Rapini, 2007). However, these efforts have achieved only a limited success in promoting collaboration (Velho and Saenz, 2002). Thus, since mid-2000s Brazil has reformed its legal and regulatory framework to incentivize university-industry collaboration. Among the actions, we highlighted the adoption of the so-called "Innovation Law" (Law No. 10.973/04), which is meant to provide incentives to increase innovation and the establishment of cooperative links between universities and business enterprises. In 2016, a "new Innovation Law” was passed (Law No. 13.243 /16) amending the previous law. The New Innovation Law provides incentives for scientific research and innovation, apart from reinforce university-industry collaboration.

In addition, Brazilian government has changing the focus of innovation policy in the country. Innovation policy has been shifted from a supply-side orientation, which emphasizes support for science, to a stronger support for business R\&D (OECD, 2014). As to the importance of this changes, we must stress that innovation policies are an essential tool for shaping the system of innovation. Despite policy efforts, Brazil's R\&D intensity has progressed slowly. The intensity of gross domestic expenditure on R\&D (GERD) increased by $1.04 \%$ of GDP in 2000, to $1.14 \%$ of GDP in 2011. A remarkably feature of Brazilian R\&D landscape is the small share of business expenditure on GERD ( $47 \%$ of total) - a common characteristic of most developing countries. Due to the fact that public sector is responsible for provisioning most of R\&D activities, both funding and performing it, universities have been playing a noteworthy role on the overall picture of the Brazilian R\&D system.

The significant role played by universities in Brazil is revealed by Suzigan and Albuquerque, (2011). The authors show that universities and other public research organizations have supported sectors and products where Brazil has international competitive advantages, such as in agribusiness, mining, aerospace industry and oil industry. These interactions were built in a long-term process involving efforts of both sides (universities and firms) and governmental support through policies and funding. Contrary to conventional wisdom, these 
findings exhibit the importance of university-industry linkages in low and medium-tech industries (Chaves et al., 2012), where relationships are based on well-established contacts and supported by public research funding (Bodas Freitas et al., 2013).

Additionally to the concentration in a few industries, university-industry collaboration in Brazil is characterized by a uneven geographical distribution (Garcia et al., 2015). Brazil underperform other countries in terms of innovative firms collaborating with universities (OECD, 2013). Results of Brazilian Innovation Survey 2011 (PINTEC) points out that only $15.9 \%$ of innovative firms have collaborated with some kind of partner on innovation (IBGE, 2013), although the rate of collaboration on innovation has increased compared to 2008.

The oil industry case is particularly important to illustrate the specificities of universityindustry collaboration in Brazil. The Brazilian state-controlled oil company, Petrobras, was created in 1953 to monopolistically exploit oil reserves, refining and transport (distribution was open to private companies). Since then, Petrobras has established a consistent relationship with several universities in Brazil, reported in case studies that have focused on specific research-intensive institutions (Lima and Silva, 2012; Poletto et al., 2011; Suslick, 2007). Collaboration on R\&D with different partners, including universities, was crucial for Petrobras to catch up from being an 'imitator' to becoming one of the 'frontier innovators' in oil industry (Dantas and Bell, 2011; Furtado and Freitas, 2000; Gielfi et al., 2013).

Nowadays, Petrobras is one of the few Brazilian companies among the world's largest R\&D investing firms (European Commission, 2014), and it is at the forefront of high-technology fields such as deep-water oil extraction.

\subsection{University-industry collaboration and $R \& D$ funding policy in the Brazilian oil industry}

Roughly, the development of Brazilian oil industry can be divided in two stages according to the institutional framework: the phase of Petrobras' monopoly and since the end of monopoly. The first phase goes from the creation of Petrobras to 1997, when the "Petroleum Law” (Law No. 9.478/97) was passed bringing Petrobras' monopoly to an end. This phase was characterized by the absence of a specific R\&D funding policy to oil and gas industry, and innovation efforts were very concentrated on Petrobras. Hence, Petrobras hold a central position at Brazilian innovation system related to oil and gas activities, funding, coordinating and carrying out most part of R\&D activities (Furtado, 2002). Nonetheless, the company invested significantly in postgraduate studies and academic research at a select group of universities in Brazil (Turchi et al., 2013). Through this strategy, academia has begun to play an import role on Petrobras’ collaborative research activities.

During the 1990's, in the context of neoliberal policies, occurred an institutional reform in the Brazilian oil and gas industry. It started with an adoption of an amendment to Article 177 of the Constitution in 1995, giving the base to the "Petroleum Law" in 1997. The Petroleum Law established a new regulatory environment to oil and gas exploration and production in the country, the general guidelines of energy policy, and create the National Petroleum Agency (ANP - responsible for regulating the oil sector). Beyond opening the sector for competition, the most significant institutional change from the Petroleum Law was regarding the R\&D funding policy with the creation of the Oil and Gas Sectoral Fund (CT-Petro).

The Oil and Gas Sectoral Fund was created to assure continuing funding to R\&D activities related to oil and gas industry in the country. The Fund is financed by a portion of additional 
royalty revenues from oil and gas production in Brazil resulting from the Petroleum Law, and managed at federal level by Finep (Federal Agency for Innovation) and the National Council for Scientific and Technological Development (CNPq). The fund follows the guidelines set in the National Plan for Science and Technology of oil industry, which is defined by a Coordination Committee under supervision of the Ministry of Science and Technology and Innovation. The members of the Committee are pointed by the Ministry of Science and Technology and Innovation, the Ministry of Mining and Energy, and the National Petroleum Agency, and it has participants for both three government bureaus, from Finep, CNPq, and representative members of business and scientific community. Its resources are assigned to Brazilian universities and others non-profit research organizations, in order to foster university-industry collaboration. The Fund aims to create conditions in which universities could transfer their research efforts to industry which, in turn, would translate it into innovation - giving it a supply-side focus. From 1999 to 2014, the Oil and Gas Sectoral Fund invested BRL 803,6 million (approximately \$228 million USD) in contracted projects.

However, the results of the Fund have fallen short of the goals. Due to disturbances in the Brazilian economy at the period, the government started to redirect a share of resources to increase primary surplus (Furtado, 2003). Thus, the gap between the resources effectively used and the amount raised to the Fund undermined one of the main goals of the policy, i.e. increased and continued funding earmarked to R\&D activities. Furthermore, limited success has been achieved by the Fund in strengthen university-industry collaboration. An evaluative study of a Public Call of the Fund shown that the policy is based on a supply-side orientation and do not promote private R\&D funding (Pereira et al., 2003). Also, the excessive resources spreading among universities and the fact that the projects are not co-executed between universities and industry, raises questions about its effectiveness in boosting the Brazilian innovation system related to oil and gas industry.

In addition to Oil and Gas Sectoral Fund' creation, the National Petroleum Agency (ANP) included an "R\&D clause" in new concession contracts concerned with the exploration and production of oil and gas, which established that any such firm (including Petrobras) must invest on $\mathrm{R} \& \mathrm{D}$ a minimum of $1 \%$ of their gross revenue generated by oil fields with high profitability or high productivity (ANP Clause No. 24, Resolution No. 33/2005 and 34/2005). At least half of this sum must be invested in public or private Brazilian-based universities or research institutes accredited by the ANP. Moreover, since 2011 it became established that at least $10 \%$ of resources must be invested in suppliers in order to improve their productive capacity related to local content rules. From 2006 to 2014, the funds destined to R\&D in Brazilian universities and research organizations generated by the ANP R\&D clause totalized over BRL 4,4 billion (approximately $\$ 1.25$ billion USD). Of this amount, 93\% (BRL 4,1 billion) relate to Petrobras (ANP, 2015).

It is worth stressing the differences between the Oil and Gas Sectoral Fund and the ANP R\&D Clause. First, there is a significant difference in the amount of resources between them, exhibits in Figure 1. Due to economic challenges above mentioned, the resources redirection of the Oil and Gas Sectoral Fund has been hampered its performance. On the other hand, the ANP R\&D Clause has gained momentum and been consolidated as the main R\&D funding instrument directed to oil and gas activities. In 2014, the resources totalized by the Fund were equivalent to less than $1 \%$ of resources invested through the ANP Clause. 
Fig.1 R\&D funding policy trends (BRL million)

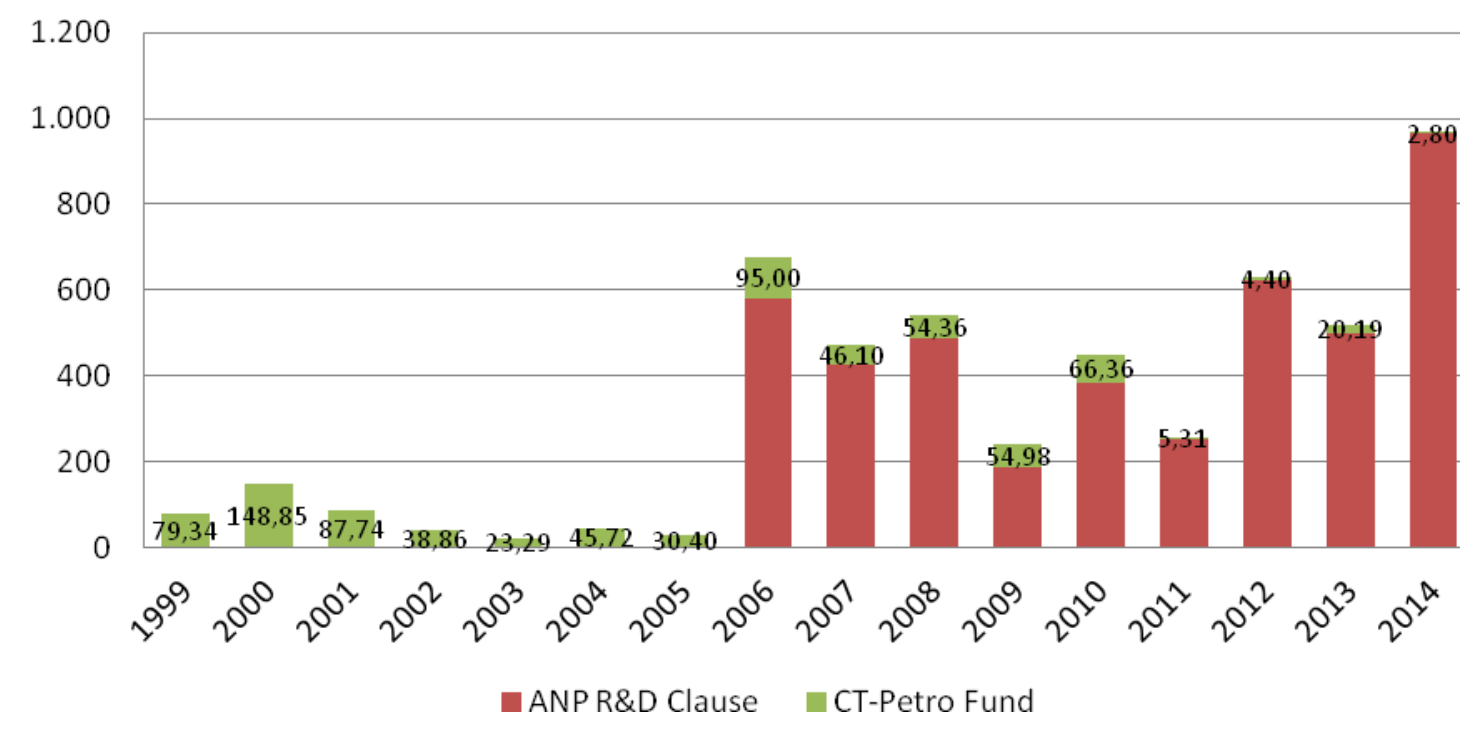

Second, they have a distinguished policy governance, which reflects upon Petrobras' coordination power. The Oil and Gas Sectoral Fund is coordinated and managed at federal level by actors from state bureaucracies, whom administer resources, define research priority areas and select the projects. This implies that there is a distinct form of coordination on R\&D activities. Within this context, Petrobras' loses its power to coordinated R\&D when compared to the monopoly phase. Nevertheless, the Fund has demonstrated a limited capacity of coordinate the oil and gas R\&D system (Furtado, 2003; Pereira et al., 2003). The ANP R\&D Clause resources are administered by the ANP, however, the agency does not define research and technology areas or targets. The ANP only supervises the use of resources, not coordinating and guiding the R\&D investments, which is done by the oil companies themselves. Thus, Petrobras restored its capacity to coordinate R\&D activities in Brazilian oil industry.

In order to coordinate and to guide its $R \& D$ projects in collaboration with Brazilian universities and research organizations, Petrobras launched a model of scientific and technological networks in 2006 which was called Thematic Networks. Currently, Petrobras has circa 50 collaborative R\&D networks to develop technologies for all its activities (Petrobras, 2013). These partnerships include the creation of cutting-edge laboratories, research training and project development. Studies suggest that these collaborative networks with universities have helped to foster innovation and knowledge creation (Ferreira and Ramos, 2015). However, apart from these contributions, there is a lack of long-term comparative data on the universities' contribution to Petrobras technological development. This paper aims to fill this gap and analyze the importance of Petrobras collaborative activities with universities to its own technological development. Therefore, we question whether the R\&D funding policy has affected Petrobras-university collaboration, strengthening the Brazilian system of innovation related to oil and gas activities.

\section{Data and methodology}

Our results are based on Petrobras' patents applications from 1980 to 2012. All patent data presented here come from CWTS-licensed version of PatStat database, the Worldwide Patent 
Statistical Database produced by the European Patent Office (EPO), and contain all patent applications by Petrobras. As these patent applications come from different jurisdictions, we used the EPO INPADOC extended patent families ${ }^{1}$ to avoid counting the same invention multiple times. The INPADOC patent family consolidates all patents protecting same or related information into a single family. To analyze Petrobras' patent portfolio as a whole, patent families may have only one patent application. A total of 1,247 patent families were retrieved during the period.

The identification of academic patents on Petrobras' portfolio was based on matching inventors' name to academic researchers' names. We manually search all the inventors' names contained in patents by Petrobras on the Lattes Platform to identify the academic researchers. The Lattes Platform is a Brazilian public database maintained by the National Council of Scientific and Technological Development (CNPq). The database integrates the résumés of researchers, students and people associated to Brazilian scientific community, providing standardized information about their scientific and academic accomplishments. The fact that the "Lattes curriculum" is used for academic evaluation and required to apply for S\&T funding, makes the registration by researchers somehow "mandatory". Thus, Lattes Platform is the main gate for ST\&I information at researcher level and its usage is disseminated through all the Brazilian scientific community. We used the available Lattes curriculums information to identify the academic researchers, their affiliation and validate the data.

Using the inventor affiliate address declared on Lattes Platform, patents were classified as 'academic joint-patent' when including at least one academic inventor. Inventors' names that led to a large data set of academic researchers' homonym names on Lattes Platform (making hand-checking not feasible) were excluded of our sample in order to avoid erroneous assignments of patents to inventors and universities. Patents were assigned to a standardized organization name on basis of their inventors' academic affiliation. All indicated universities were considered, thus a single patent can be invented by multiples universities. A total of 216 academic joint-patents were identified in the Petrobras’ patent portfolio.

The intensity of collaboration was calculated as the ratio of Petrobras' academic joint-patents to the total number of Petrobras' patents. The Petrobras' collaboration networks are based on inventors' affiliation and were created using UCINET software. As to analyze the extent that universities contribute to Petrobras' technological development in distinct technical fields, we rely on all the International Patent Classification (IPC) classes contained in patents of Petrobras.

\section{Results}

The first part of our analysis is focused on capturing the changes in Petrobras-university inventive collaboration overtime. In doing so, we address the extent to which R\&D funding policy has affected the intensity of collaboration. Table 1 exhibits, for each policy phases, changes in the magnitude and intensity of Petrobras-university collaboration. The 1980-1998 period marks the phase in which Petrobras monopolized oil and gas exploration and production activities in Brazil. The 1999-2005 phase is characterized by the establishment of

\footnotetext{
1 The patent linkages considered for INPADOC extended patent families are: Paris Convention priorities, domestic continuations and technical relations (Martinez, 2010).
} 
a R\&D funding policy to oil industry through the creation of the Oil and Gas Sectoral Fund. The 2006-2012 phase is marked by the implementation of the ANP R\&D clause.

Table 1 Petrobras-university inventive collaboration trends

\begin{tabular}{|l|c|c|c|}
\hline \multicolumn{1}{|c|}{ Phase/output-intensity } & $\begin{array}{c}\text { (1) 1980- } \\
\mathbf{1 9 9 8}\end{array}$ & $\begin{array}{c}\text { (2) 1999- } \\
\mathbf{2 0 0 5}\end{array}$ & $\begin{array}{c}\text { (3) 2006- } \\
\mathbf{2 0 1 2}\end{array}$ \\
\hline Petrobras' patent applications output & 543 & 297 & 447 \\
\hline Average Petrobras' patent applications per year & 30 & 49 & 74 \\
\hline Petrobras' academic joint-patent applications output & 44 & 41 & 131 \\
\hline $\begin{array}{l}\text { Average Petrobras' academic joint-patent } \\
\text { applications per year }\end{array}$ & 2 & 6 & 21 \\
\hline Petrobras' academic joint-patent intensity & $8 \%$ & $14 \%$ & $29 \%$ \\
\hline
\end{tabular}

Our results reveal an upward trend in Petrobras' patenting activity. The average number of patents applications by Petrobras per year has grown from 30 to 74 patent families during the years 1980-2012. The growing importance of collaboration with universities in patenting activity of Petrobras is shown by the increasing average number of patents per year overtime. Moreover, the table shows an increase in Petrobras' academic joint-patent intensity, which is calculated as the ratio of academic joint-patents to the total number of Petrobras' patents. Our results also reveal a remarkable increase in the intensity of collaboration in the last phase (2006-2012), when the intensity of collaboration doubled compared to the previous phase.

Table 2 displays the top 10 main university research partners of Petrobras ranked by the number of joint-patents applications during from 1980 to 2012. This group of universities comprises mostly Brazilian public institutions, except for Pontifical Catholic University of Rio de Janeiro, which is a private institution. Besides concentrating collaboration, this group of universities also concentrate $28 \%$ of Petrobras' R\&D investments from the ANP R\&D Clause from 2006 to March 2015. It is worth saying that over 100 Brazilian universities and research organizations have received Petrobras investments from ANP R\&D Clause during this period.

Table 2 Top 10 Petrobras’ academic partners in patenting: 1980-2012

\begin{tabular}{|l|c|c|c|}
\hline & Number of patents & \% Total & \% ANP R\&D Clause* \\
\hline Univ Fed Rio De Janeiro & 79 & $6 \%$ & $10.5 \%$ \\
\hline Pontificia Univ Catolica Rio De Janeiro & 28 & $2 \%$ & $3.24 \%$ \\
\hline Univ Sao Paulo & 17 & $1 \%$ & $1.70 \%$ \\
\hline Univ Fed Rio Grande Sul & 13 & $1 \%$ & $1.83 \%$ \\
\hline Univ Estadual Campinas & 13 & $1 \%$ & $2.17 \%$ \\
\hline Univ Fed Fluminense & 12 & $1 \%$ & $1.80 \%$ \\
\hline Univ Estado Rio De Janeiro & 11 & $1 \%$ & $1.36 \%$ \\
\hline Univ Fed Rio Grande Do Norte & 10 & $1 \%$ & $2.62 \%$ \\
\hline Univ Fed Santa Catarina & 6 & $0 \%$ & $2.07 \%$ \\
\hline Univ Brasilia & 6 & $0 \%$ & $0.71 \%$ \\
\hline
\end{tabular}

*Share of Petrobras' investment from ANP R\&D Clause received by institution from 2006 to March 2015 
To examine how collaboration evolves over time at the university-level, Figure 2 represents all collaborative links between Petrobras and universities for each phase. Our results show that the number and intensity of collaborative linkages between Petrobras and universities scarcely changed from phase 1 (1980-1998) to phase 2 (1999-2005). As a matter of fact, the magnitude of collaboration decreased during 1999-2005 compared to the previous phase of the monopoly of Petrobras. However, Figure 2c shows a striking change in collaboration during 2006-2012. Petrobras' collaborative network substantially broadened in this period, with an increase in the number of universities partners involved in patenting activities.

Beyond the inclusion of new universities partners, the collaboration among universities clearly increased during 2006-2012. In other words, universities have become more interconnected, suggesting that Petrobras-universities' patenting activity is organized as research consortia. Figure $2 \mathbf{c}$ also reveals that some universities have become central actors in Petrobras' inventive networks, such as the Federal University of Rio de Janeiro and the Pontifical Catholic University of Rio de Janeiro.

Fig.2 Petrobras’ collaboration networks

Fig.2a: Phase 1 (1980-1998)

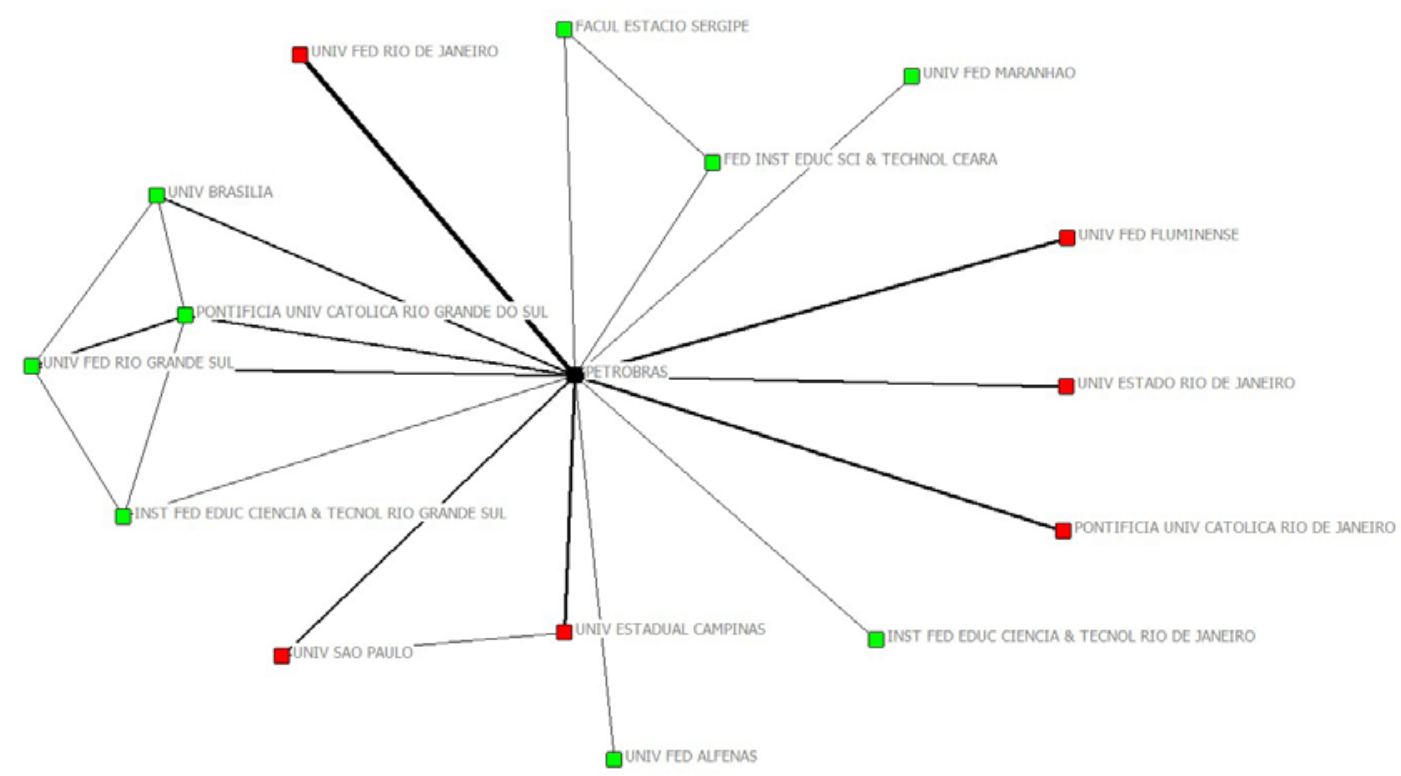

Fig.2b: Phase 2 (1999-2005) 


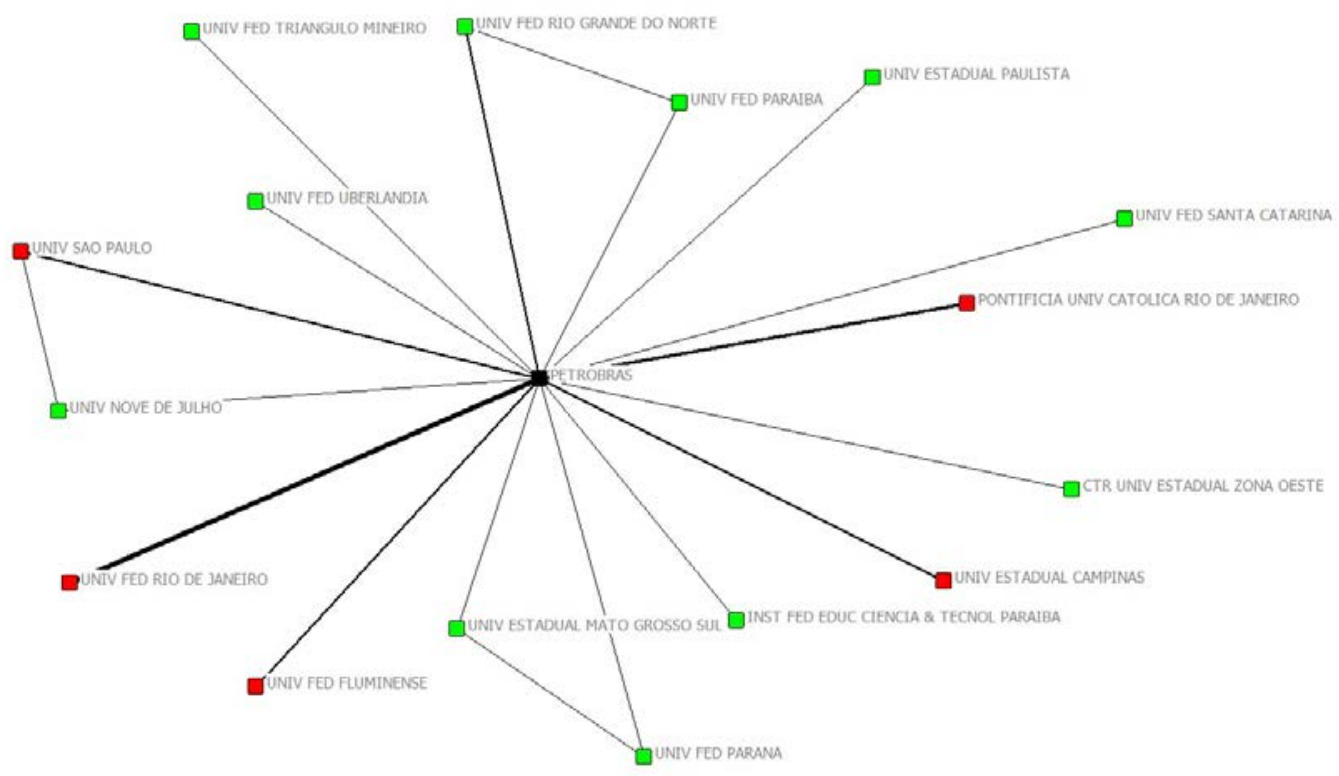

Fig.2c: Phase 3 (2006-2012)

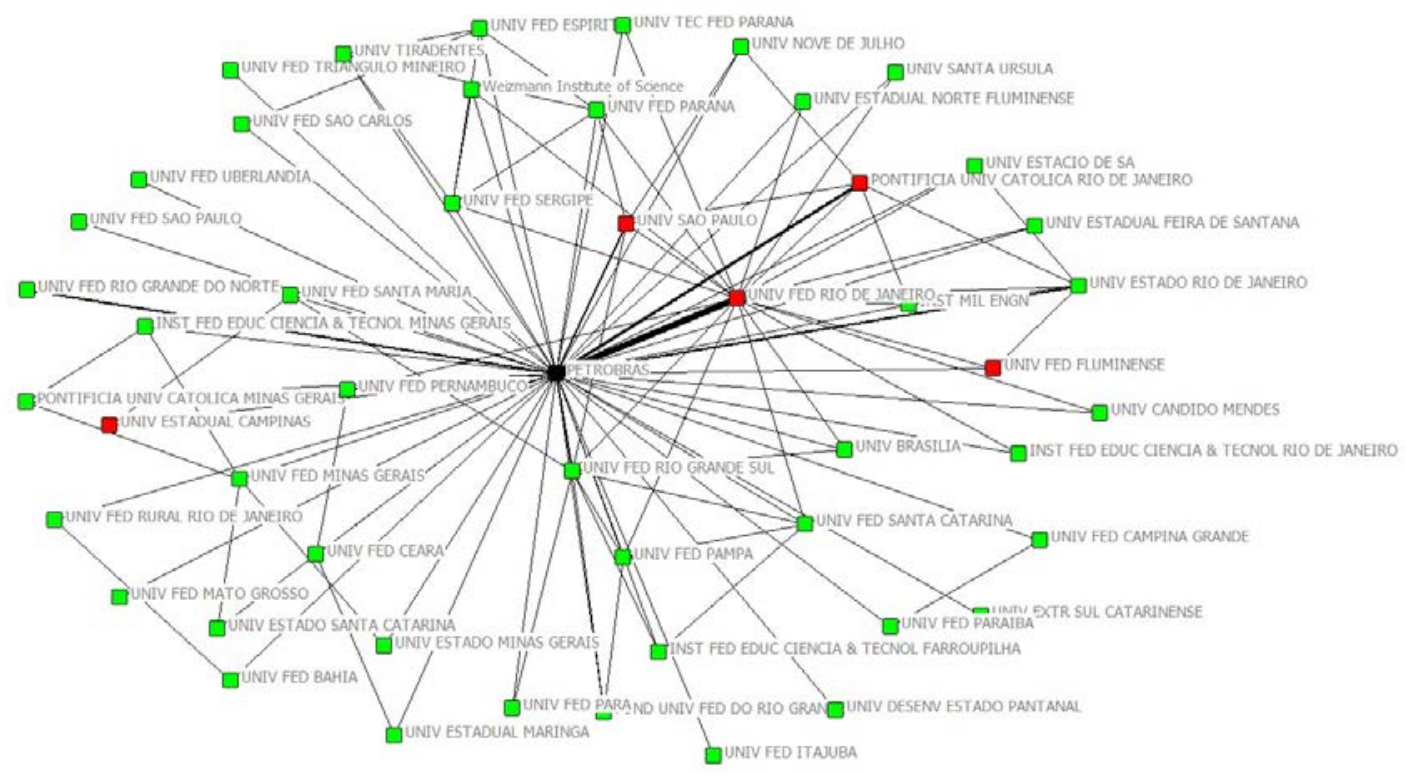

The second part of our data analysis is focused on how collaboration with universities support Petrobras' technological development. One way of addressing these issues is by relating the degree to which academic patents are specialized in a given technical field to the share the field has in terms of all Petrobras' patenting. Therefore, we adapted the Granstrand et al. (1997) framework for companies' technological profiles to measure and classify the 
contribution of universities to Petrobras' technological competencies. The quadrant is based on the Petrobras' Revealed Technological Advantage (RTA) Index ${ }^{2}$ (X-axis) and the patent share (Y-axis). The RTA Index is calculated by the share of academic joint-patents in a given IPC sub-class to the share of all Petrobras' patents in the same IPC sub-class. Thus, RTA provides an indication of the relative technological specialization of Petrobras-university collaboration within Petrobras' patent portfolio. The Y-axis reflects the relative importance of each IPC sub-class (technological field) in Petrobras’ patent portfolio.

We distinguish four quadrants, as seen in Figure 3. Quadrant I (core contributions) represents technological fields in which academic joint-patents are considerable specialized and account for a relatively large share on all Petrobras' patent portfolio. Quadrant II (background contributions) shows technical fields in which Petrobras' patenting activity is comparably high, but academic contribution is not as strong. Quadrant III (marginal contributions) represents the technological fields in which both Petrobras' patenting activity and academic joint-patents are relatively low. In the Quadrant IV (niche contributions) are the technical fields in which there is a relative contribution of universities, but there is little patenting activity by Petrobras.

Fig.3 Universities contributions within Petrobras’ technological portfolio: 2006-2012 (IPC 4-digit sub-class in which Petrobras’ patent applications output $>=10$ )

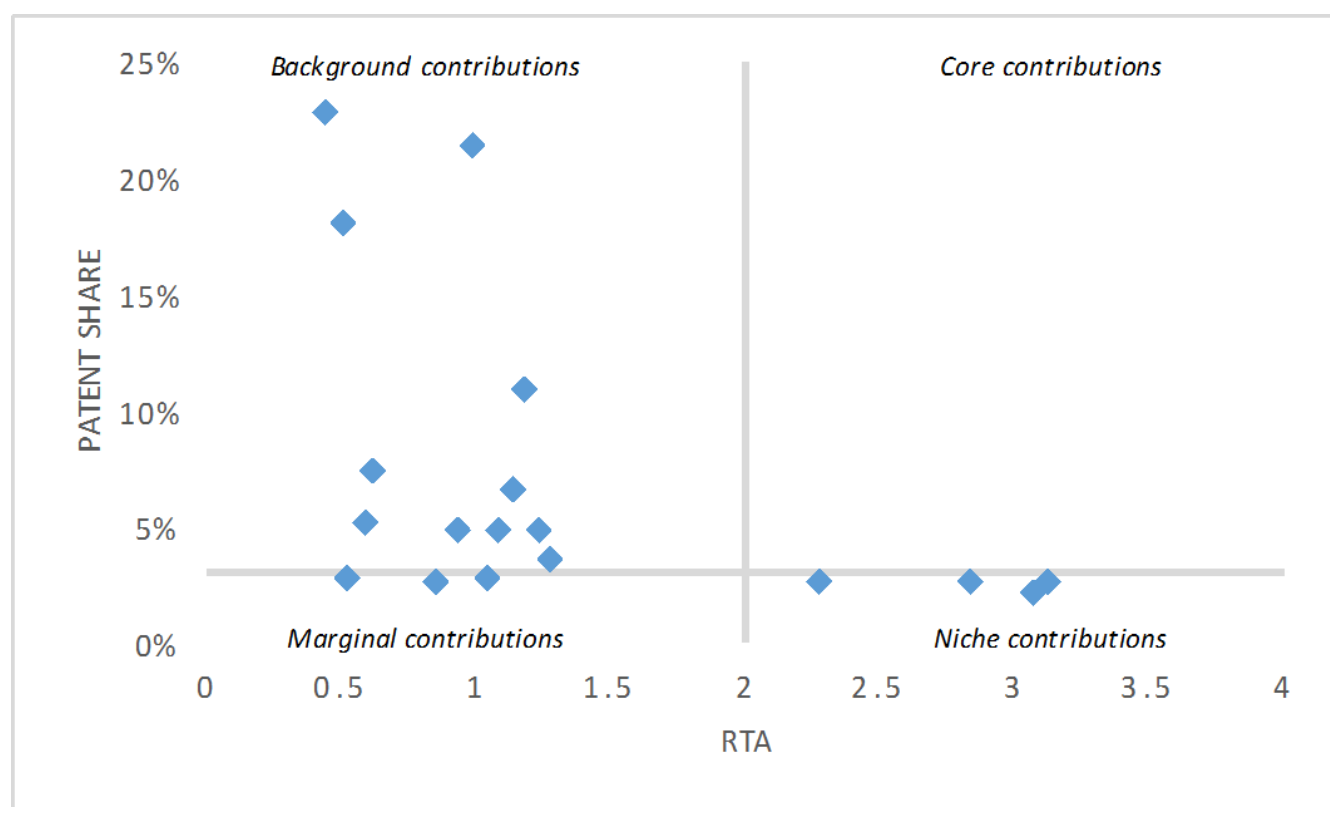

Thereby, Figure 3 shows what kind of contributions universities have made to Petrobras' technological competencies. Universities have made mainly background and niche contributions. Background contributions concentrated $61 \%$ of academic joint-patents, and niche areas centered $22 \%$ of academic joint-patents among the technical fields in which Petrobras has 10 or more patents during 2006-2012. The niche contributions are oriented to biochemistry and treatment of water, sewage or sludge, while background contributions are

\footnotetext{
${ }^{2}$ RTA Index can be normalized to provide a symmetrically comparison of results, without affect the ranking position of RTA values, see (Brusoni and Geuna, 2005; Nesta and Patel, 2005).
} 
focused on technical fields more closely related to oil and gas exploration, such as earth or rock drilling, and petroleum, gas and coke industries.

\section{Conclusions}

This paper analyzed Petrobras-university collaboration during 1980-2012 based on patent data. The empirical results reveal an increasing collaboration between Petrobras and Brazilian universities, which has substantially changed after the establishment of the R\&D funding instrument aforementioned. Thus, Petrobras' network collaboration has increased the number of universities research partners, as well as strengthened the intensity of collaboration. Universities have somehow contributed to reinforce Petrobras' technological competencies and brought new technical expertise, expanding and diversifying the company's technological portfolio.

Our findings show that certain degree of success has been achieved by the R\&D funding policy, since it becomes clear that in the period Petrobras-university collaboration has expanded. However, the fact that public universities are supporting Petrobras' technological base in background and niche technologies raises questions regarding whether collaboration has strengthening the technological capabilities of the company. Although universities contributions are mainly centered in fields closely related to oil and gas exploration, they have made no core contributions to the patent portfolio of Petrobras. Thus, there is no conclusive evidence about the effectiveness and impact of R\&D funding policy to foster the technological capabilities of Petrobras via collaboration with universities.

Further research is needed to response this unanswered question. Follow-up interviews can be used to obtain qualitative information about the importance of collaboration improve the technological capabilities of Petrobras. One might argue that the recent upturn in Petrobrasuniversity inventive collaboration could be good news for Brazilian universities rather than the company itself. As it seems that collaboration has been driven by the increasing R\&D funding and fostering the capabilities of the universities - in terms of orientation to applied research and/or technological development activities - but, with little impact on developing the company technological competencies. Thus, the policy may have null effect on improve Petrobras’ capabilities.

Some interesting policy issues can be raised from our findings. First, the extent to which universities collaboration has spilled-over Petrobras' networks remains an open question. The R\&D funding policy should pay special attention to the need of enhancing collaboration between universities and Petrobras while bringing together other actors, especially supply companies. Further research is needed to examine whether university research collaboration on technological development goes beyond Petrobras, involving other actors in oil industry.

The second policy implication concerns intellectual property rights. The higher the number of universities partners involved in collaboration, the more difficult it becomes to appropriate the outcomes of collaborative efforts for the partners involved, with the university incurring in danger of being misrepresented in patents applications. This is further reinforced by the fact that co-owned patents are generally seen as a suboptimal option for firms.

\section{References}


Albuquerque, E.M., Suzigan, W., Kruss, G., Lee, K. (Eds.), 2015. Developing National Systems of Innovation: university-industry interactions in the Global South. Edward Elgar, Cheltenham, UK e Northampton, MA, USA.

ANP, 2015. Anuário estatístico brasileiro do petróleo, gás natural e biocombustíveis 2015. Rio de Janeiro.

Bekkers, R., Bodas Freitas, I.M., 2008. Analysing knowledge transfer channels between universities and industry: To what degree do sectors also matter? Res. Policy 37, 18371853. doi:10.1016/j.respol.2008.07.007

Bodas Freitas, I.M., Marques, R.A., Silva, E.M.D.P.E., 2013. University-industry collaboration and innovation in emergent and mature industries in new industrialized countries. Res. Policy 42, 443-453. doi:10.1016/j.respol.2012.06.006

Breschi, S., Lissoni, F., Malerba, F., 2003. Knowledge-relatedness in firm technological diversification. Res. Policy 32, 69-87. doi:10.1016/S0048-7333(02)00004-5

Brusoni, S., Geuna, A., 2005. Specilialisation and Integration: combining patents and publications data to map the "structure" of specialised knowledge, in: Moed, H.F., Glänzel, W., Schmoch, U. (Eds.), Handbook of Quantitative Science and Technology Research. Springer, Netherlands, pp. 733-758.

Campos, A.L.S., 2010. A review of the influence of long-term patterns in research and technological development (R\&D) formalisation on university-industry links. Rev. Bras. Inovação 9, 379-409.

Chaves, C.V., Carvalho, S.S.M., Silva, L.A., Teixeira, T.C., Bernardes, P., 2012. The point of view of firms in Minas Gerais about the contribution of universities and research institutes to R\&D activities. Res. Policy 41, 1683-1695. doi:10.1016/j.respol.2012.07.008

Cohen, W.M., Nelson, R.R., Walsh, J.P., 2002. Links and Impacts : The Influence of Public Research on Industrial R\&D. Manage. Sci. 48, 1-23.

Currie, I., 2011. Government Policies to Encourage University-Business Research Collaboration in Canada: Lessons from the US, the UK and Australia, CSLS Research Report 2011-02.

Dantas, E., Bell, M., 2011. The Co-Evolution of Firm-Centered Knowledge Networks and Capabilities in Late Industrializing Countries: The Case of Petrobras in the Offshore Oil Innovation System in Brazil. World Dev. 39, 1570-1591. doi:10.1016/j.worlddev.2011.02.002

Dutrénit, G., Arza, V., 2010. Channels and benefits of interactions between public research organisations and industry: comparing four Latin American countries. Sci. Public Policy 37, 541-553. doi:10.3152/030234210X512043

Eisenhardt, K.M., 1989. Building theories from case study research. Acad. Manag. Rev. 14, 532-550.

European Commission, 2014. The 2014 EU Industrial R\&D Investment Scoreboard. doi:10.2791/13983

Ferreira, M.L.A., Ramos, R.R., 2015. Making University-Industry Technological Partnerships Work: a Case Study in the Brazilian Oil Innovation System. J. Technol. Manag. Innov. 10, 173-187. doi:10.4067/S0718-27242015000100013

Freeman, C., 1987. Technology Policy and Economic Performance: Lessons from Japan. Pinter Publishers, London.

Furtado, A.T., 2003. Mudança institucional e inovação na indústria brasileira de petróleo. Rev. Bras. Energ. 9, 1-12.

Furtado, A.T., 2002. Mudança institucional e inovação na indústria brasileira de petróleo. Rev. Bras. Energ. 9, 1-12. 
Furtado, A.T., Freitas, A.G., 2000. The catch-up strategy of Petrobras through cooperative R\&D. J. Technol. Transf. 25, 23-36. doi:10.1023/A:1007882903341

Garcia, R., Araujo, V., Mascarini, S., Gomes Santos, E., Costa, A., 2015. Looking at both sides: how specific characteristics of academic research groups and firms affect the geographical distance of university-industry linkages. Reg. Stud. Reg. Sci. 2, 517-533. doi:10.1080/21681376.2015.1099464

Geuna, A., Nesta, L., 2006. University patenting and its effects on academic research: The emerging European evidence. Res. Policy 35, 790-807. doi:10.1016/j.respol.2006.04.005

Gielfi, G.G., Pereira, N.M., Gomes, R., Fornari, V.C.D.B., 2013. User-Producer Interaction in the Brazilian Oil Industry: The Relationship Between Petrobras and its Suppliers of Wet Christmas Tree. J. Technol. Manag. Innov. 8, 117-127.

Granstrand, O., Patel, P., Pavitt, K., 1997. Multi-Technology Corporations: Why they have “distributed” rather than “distinctive core” competencies. Calif. Manage. Rev. 39, 8-25. doi:Article

Griliches, Z., 1990. Patent Statistics as Economic Indicators: A Survey. J. Econ. Lit. 28, 1661-1707. doi:10.1016/S0169-7218(10)02009-5

IBGE, 2013. Pesquisa de Inovação - PINTEC. Brasília.

Klevorick, A.K., Levin, R.C., Nelson, R.R., Winter, S.G., 1995. On the sources and significance of interindustry differences in technological opportunities. Res. Policy 24, 185-205. doi:10.1016/0048-7333(93)00762-I

Laursen, K., Salter, A., 2004. Searching high and low: what types of firms use universities as a source of innovation? Res. Policy 33, 1201-1215.

Lima, M.F. da C., Silva, M.A., 2012. Inovação em petróleo e gás no Brasil: a parceria Cenpes-Petrobras e Coppe-UFRJ. Soc. e Estado 27, 97-115.

Lissoni, F., 2012. Academic patenting in Europe: An overview of recent research and new perspectives. World Pat. Inf. 34, 197-205. doi:10.1016/j.wpi.2012.03.002

Lundvall, B.-Å. (Ed.), 1992. National Systems of Innovation: Towards a theory of innovation and interactive learning, Towards a theory of innovation and interactive learning. Pinter, London.

Mansfield, E., 1995. Academic research underlying industrial innovations: sources, characteristics, and financing. Rev. Econ. Stat. 77, 55-65.

Martinez, C., 2010. INSIGHT INTO DIFFERENT TYPES OF PATENT FAMILIES (No. 2), OECD Science, Technology and Industry Working Papers. Paris.

Mazzoleni, R., 2008. Catching Up and Academic Institutions: A Comparative Study of Past National Experiences. J. Dev. Stud. 44, 678-700. doi:10.1080/00220380802009175

Mazzoleni, R., Nelson, R.R., 2007. Public research institutions and economic catch-up. Res. Policy 36, 1512-1528. doi:10.1016/j.respol.2007.06.007

Meyer-Krahmer, F., Schmoch, U., 1998. Science-based technologies: university-industry interactions in four fields. Res. Policy 27, 835-851. doi:10.1016/S0048-7333(98)000948

Meyer, M., 2003. Academic patents as an indicator of useful research? A new approach to measure academic inventiveness. Res. Eval. 12, 17-27.

Mowery, D.C., Sampat, B.N., 2005. Universities in National Innovation Systems, in: Fagerberg, J., Mowery, D.C., Nelson, R.R. (Eds.), The Oxford Handbook of Innovation. Oxford University Press, Oxford, pp. 209-239.

Narin, F., Hamilton, K.S., Olivastro, D., 1997. The increasing linkage between US technology and public science. Res. Policy 26, 317-330.

Narin, F., Noma, E., Perry, R., 1987. Patents as indicators of corporate technological strength. Res. Policy 16, 143-155. doi:10.1016/0048-7333(93)90052-J 
Nelson, R.R., 1993. National Innovation Systems: a comparative analysis. Oxford University Press, New York.

Nesta, L., Patel, P., 2005. National Patterns of Technology Accumulation: Use of Patent Statistics. Handb. Quant. Sci. Technol. Res. 531-551. doi:10.1002/(SICI)15206378(199908)24:4<297::AID-COL11>3.3.CO;2-6

OECD, 2014. Brazil, in: OECD Science, Technology and Industry Outlook 2014. OECD Publishing, Paris, pp. 280-283. doi:10.1787/sti_outlook-2014-39-en

OECD, 2013. Commercialising Public Research. doi:10.1787/9789264193321-en

OECD, 2009. OECD Patent Statistics Manual. OECD Publishing, Paris. doi:10.1787/9789264056442-en

Pavitt, K., 1998. Do patents reflect the useful research output of universities? Res. Eval. 7, 105-111. doi:10.1093/rev/7.2.105

Pavitt, K., 1991. What makes basic research economically useful? Res. Policy 20, 109-119. doi:10.1016/0048-7333(91)90074-Z

Pavitt, K., 1988. Uses and abuses of patent statistics, in: van Raan, A.F.J. (Ed.), Handbook of Quantitative Studies of Science and Technology. Elsevier Science Publishers B.V., North-Holland, pp. 509-536.

Pereira, N.M., Furtado, A.T., Freitas, A.G., Martins, F.C., Santos, A.M.R., 2003. Perfil dos projetos financiados pelo CT-Petro. Parcerias Estratégicas 8, 215-249.

Perkmann, M., Walsh, K., 2007. University-industry relationships and open innovation: Towards a research agenda. Int. J. Manag. Rev. 9, 259-280. doi:10.1111/j.14682370.2007.00225.x

Petrobras, 2013. Relatório de Tecnologia Petrobras.

Poletto, C.A., Araújo, M.A.D. De, Mata, W. Da, 2011. Gestão compartilhada de P\&D: o caso da Petrobras e a UFRN. Rev. Adm. Pública 45, 1095-1117. doi:10.1590/S003476122011000400009

Rapini, M.S., 2007. Interação universidade-empresa no Brasil: evidências do Diretório dos Grupos de Pesquisa do CNPq. Rev. Econ. Contemp. 11, 99-117. doi:10.1590/S141598482007000100004

Salter, A.J., Martin, B.R., 2001. The economic benefits of publicly funded basic research: a critical review. Res. Policy 30, 509-532. doi:10.1016/S0048-7333(00)00091-3

Silva, K., Godinho, M.M., Tonholo, J., Uchoa, S.B.B., Vasconcellos, A.G., 2014. PATENTES ACADÊMICAS X PATENTES UNIVERSITÁRIAS: UMA AVALIAÇÃO DO INVENTOR ACADÊMICO NAS PATENTES DEPOSITADAS PELA VIA PCT 2002-2012. Cad. Prospecção 7, 335-344. doi:10.9771/S.CPROSP.2014.007.034

Suslick, S.B., 2007. Strategic university-industry partnership in petroleum: the case of Cepetro/Unicamp as a brazilian innovative experience. Brazilian J. Pet. Gas 1, 59-66.

Suzigan, W., Albuquerque, E.M., 2011. The underestimated role of universities for the Brazilian system of innovation. Rev. Econ. Política 31, 03-30.

Thursby, J., Fuller, A.W., Thursby, M., 2009. US faculty patenting: Inside and outside the university. Res. Policy 38, 14-25. doi:10.1016/j.respol.2008.09.004

Tijssen, R.J.W., 2005. Measuring and evaluating science-technology connections and interactions, in: Moed, H.F., Glänzel, W., Schmoch, U. (Eds.), Handbook of Quantitative Science and Technology Research: The Use of Publication and Patent Statistics in Studies of S\&T Systems. Kluwer Academic Publisher, New York, pp. 695715.

Trajtenberg, M., 1990. A penny for your quotes: patent citations and the value of innovations. RAND J. Econ. 21, 172-187. doi:10.2307/2555502

Turchi, L., De Negri, F., De Negri, J.A. (Eds.), 2013. Impactos tecnológicos das parcerias da 
Petrobras com universidades, centros de pesquisa e firmas brasileiras. IPEA, Brasília. van Dongen, P., Winnink, J., Tijssen, R.J.W., 2014. Academic inventions and patents in the Netherlands: A case study on business sector exploitation. World Pat. Inf. 38, 27-32. doi:10.1016/j.wpi.2014.03.002

Velho, L., Saenz, T.W., 2002. R\&D in the public and private sector in Brazil: complements or substitutes?, UNU/INTECH Discussion Papers, 1564-8370.

Velho, L., Velho, P., Davyt, A., 1998. Las políticas e instrumentos de vinculación en los países del MERCOSUR. Educ. Super. y Soc. 9, 51-76. 